\title{
PUBLIC CONCERNS ABOUT WATER POLLUTION BETWEEN 2002 AND 2017 IN THE PACIFIC NORTHWEST, USA
}

\author{
ROBERT L. MAHLER ${ }^{1}$, MICHAEL E. BARBER ${ }^{2} \&$ ROBERT SIMMONS ${ }^{3}$ \\ ${ }^{1}$ Department of Soil and Water Systems, University of Idaho, USA \\ ${ }^{2}$ Department of Civil and Environmental Engineering, University of Utah, USA \\ ${ }^{3}$ Jefferson County Extension, Washington State University, USA
}

\begin{abstract}
Water is considered the most important natural resource in the four Pacific Northwestern states (Alaska, Idaho, Oregon and Washington). Public attitudes about water resource issues and needs were determined using a mail-based survey instrument every 5 years (2002, 2007, 2012 and 2017). The survey questions were identical over the 15 -year period. The statistically designed survey study was also designed to measure change over the 15 -year time period. Four specific survey questions were evaluated in this article. In 2017, over $83 \%$ of the public considered their home drinking water safe; however, this value was lower and compared unfavourably to the $93.1 \%$ who considered their drinking water safe in 2002. In 2017, 43.8, 40.7, 28.3, 25.3, 19.4 and $14.8 \%$ of residents considered phosphates, nitrates, pesticides, pharmaceuticals, petroleum products and pathogens as problems in local waters, respectively. Compared to the 2002 survey, the perceived problem of phosphates, nitrates and pharmaceuticals has become worse; however, public views of problems caused in waters by pesticides and petroleum products have lessened. Based on public perception, the problem of pathogens in waters has not changed over the 15-year span. Surface water and groundwater quality were considered to be excellent or good by 51.6 and $46.2 \%$ of survey respondents in 2017 , respectively. In general, public views of water quality have improved since 2002.

Keywords: drinking water, public concerns, public opinion, water contaminants, water quality, water quantity.
\end{abstract}

\section{INTRODUCTION}

Water resources are key to the economy of the Pacific Northwest (Alaska, Idaho, Oregon and Washington). Water supports agriculture $(5,000,000$ irrigated ha), commerce, power production, direct human water consumption, food processing and recreation. Previously conducted surveys have shown than that the public within the region consider water their most important natural resource and that there are significant concerns about both water quality and water quantity issues within these four states [1,2].

\section{BACKGROUND}

When drinking water, food production, food preparation, sanitation and hygiene are considered, the United Nations suggests that each human needs in excess of 900,000 l of water each year to meet their needs [1-5], From a drinking water standpoint, humans require between 1.8 and $2.0 \mathrm{l} / \mathrm{d}$ of high-quality water [3-5]. Written records indicate that humans have treated or protected drinking water supplies in some fashion for over 5,000 years [6]. The quantity, quality and safety of drinking water is a priority for local governments across the globe. In fact, the quantity and safety of drinking water is considered by the United Nations as Sustainable Development Goal number 6.

Many contaminants have been identified in surface and/or groundwater. Nitrogen is the major nutrient applied to crops across the planet and one of its forms, nitrate, often leaks into surface and groundwater resources [7,8]. Nitrate, as a contaminant in drinking water 
supplies, can adversely impact infants, causing blue baby syndrome (methemoglobinemia). Reduced water quality problems associated with phosphorus are generally confined to surface waters and can lead to eutrophication $[8,9]$. Poor agricultural practices that result in soil erosion and manures reaching waters from animal feeding operations are the most common ways by which $P$ is introduced into waters. More recently, pharmaceuticals associated with sewer systems have become contaminants of concern in water systems [10]. Public surveys conducted about drinking water in the USA, Canada, Great Britain, France, South Africa and Japan have shown both a high level of satisfaction with quality, but also concerns about taste and specific contaminants [11-13].

To understand the water cycle, one must recognize the link between surface water and groundwater which must be understood to effectively manage water resources on a local, regional, national and international basis. The public in the Pacific Northwest has been exposed to water issues repeatedly by the media in the last four decades, yet their understanding is not widely known.

The purpose of this article was to document changes about public perceptions of: (1) drinking water safety, (2) surface water quality, (3) groundwater quality and (4) the prevalence of pollutants in local water over a 15 -year period from 2002 to 2017 . This study was conducted in the Pacific Northwest region of the USA which encompasses the states of Alaska, Idaho, Oregon and Washington. This region comprises $26 \%$ of the USA's land area.

\section{METHODOLOGY}

A survey instrument containing 60 questions was developed to access public attitudes, priorities and concerns about water resource issues in the Pacific Northwest, USA. This survey was first distributed to the public in 2002. Identical survey questions were administered again in 2007, 2012 and 2017. Consequently, all the four surveys contained the four identical questions which are the topic of this article:

1. Do you feel that your home tap drinking water is safe to drink? Answer choices: yes, no

2. In your opinion, what is the QUALITY of surface water where you live? Answer choices: excellent or good, fair, poor, no opinion

3. In your opinion, is the QUANTITY of surface water enough to meet human needs? Answer choices: more than adequate, adequate, less than adequate, much less than adequate, no opinion

4. Do you know of or suspect that any of the following pollutants negatively affect surface or groundwater quality in your area? Specific pollutants questioned were pathogens, nitrates, phosphates, heavy metals, minerals, pesticides, salinity, pharmaceuticals, petroleum products and algae. Answer choices: know it is not a problem, suspect it is not a problem, don't know, suspect it is a problem, know it is a problem

The survey target audience was a representative sample of the 9,000,000 adult residents of Idaho, Oregon and Washington that live within the four Pacific Northwest states (Alaska, Idaho, Oregon and Washington). In addition, demographic information, including state of residence, community size, length of time residing in the region, gender, age and educational level were also collected from survey respondents.

In each survey year, a target of 1,000 completed questionnaires was chosen as the survey goal to result in a sampling error of 4-6\% [14]. The survey process was designed to receive a completed survey return rate more than $50 \%$. Addresses were obtained from a professional 
social sciences survey company (SSI, Norwich, CT, USA). Four mailings were planned to achieve the $50 \%$ return rate $[15,16]$. The mailing strategy used was identical in all four surveys that had been conducted in the region since $2002[1,2]$.

It only took three mailings to achieve the target return rate of 50\% in 2002, 2007 and 2012. Conversely, it took four mailings to achieve the $50 \%$ return rate in 2017 . The first mailing included the water issues survey form, a business reply envelope and a cover letter that: (1) identified the survey's authors, (2) explained the purpose of the survey, (3) assured the respondent of anonymity and (4) asked the respondents to fill out and return the survey via the business reply envelope. The second mailing ( 4 weeks later) consisted of a postcard that stressed the importance of the survey and reminded the respondent to fill out and return the survey sent out in the first mailing. Five weeks later, the third mailing was sent to residents who did not respond to the first or second mailing. This mailing included a reminder letter, another copy of the water issues survey and a business reply envelope. The fourth mailing, used in 2017, consisted of a reminder postcard 6 weeks after the third mailing.

Survey answers were coded and entered into Microsoft Excel. Missing data were excluded from the analysis. The data were analysed at two levels using SAS [16]. The first level of analysis generated frequencies, while the second level evaluated the impacts of demographic factors. Significance $(\mathrm{P}<0.05)$ to demographic factors was tested using a chi-square distribution [14-16]. Since similar response rates were observed in all four survey years, data analysis procedures were identical for each sampling.

\section{RESULTS AND DISCUSSION}

All four survey years achieved a survey return rate more than $50 \%$. This high response rate coupled with the survey design assured that the survey results achieved values that were within a sampling error of less than 5\% [14]. When averaged over the four survey years, $51.4 \%$ of the survey respondents were male. Over $41 \%$ of survey respondents lived in communities of more than 100,000 people. Conversely, $16.2 \%$ of respondents lived in towns with less than 7,000 people. Almost half of the survey respondents attended at least 1.5 years of college. The demographics of the survey respondents mirrored the 1990, 2000 and 2010 USA census data. Thus, the survey respondents were representative of the actual population living in the Pacific Northwest. Consequently, when coupled with the low sampling error of the survey, respondents can be equated to residents in the following discussion.

\subsection{Satisfaction with drinking water quality}

Satisfaction with drinking water was used as an indirect measure of water pollution in the Pacific Northwest. Based on the results of the 2017 survey, 83.1\% of Pacific Northwest residents believe that their home tap drinking water is safe (Table 1). This result was good and encouraging. Over the 15-year span of this survey study, a large majority of people have believed that their drinking water supply is safe; however, satisfaction with this safety has slipped from $91.3 \%$ in 2002 down to $83.1 \%$ in 2017 . This difference is statistically significant $\left(\mathrm{P}=0.006^{* * *}\right)$. The bottom line is that eight out of ten residents are satisfied with the safety of their drinking water, but the erosion of satisfaction in the last 15 years should be addressed.

The demographic factors of gender, age, education level and community size impacted how residents viewed the safety of their drinking water in 2017 (Table 2). Males (86.4\%) were more likely than females (79.8\%) to view their drinking water as safe. This observation was also true for the 2002, 2007 and 2012 surveys. Respondent age also significantly 
Table 1: Public views about the safety of drinking water in the Pacific Northwest based on 2002, 2007, 2012 and 2017 surveys.

\begin{tabular}{lllll}
\hline Answer & $2002(\%)$ & $2007(\%)$ & $2012(\%)$ & $2017(\%)$ \\
\hline Yes, drinking water is safe & 91.3 & 89.3 & 86.2 & 83.1 \\
No, drinking water is not safe & 8.7 & 10.7 & 13.8 & 16.9 \\
\hline
\end{tabular}

Table 2: The influence of the demographic factors of gender, age, education level and community size on the perceived safety of drinking water supplies in the Pacific Northwest based on the 2017 water resources survey.

\begin{tabular}{lllll}
\hline $\begin{array}{l}\text { Demographic } \\
\text { factor }\end{array}$ & Parameter & $\begin{array}{l}\text { DW is } \\
\text { safe }(\%)\end{array}$ & $\begin{array}{l}\text { DW is not } \\
\text { safe }(\%)\end{array}$ & Significance \\
\hline Gender & Female & 79.8 & 20.2 & $* * *$ \\
Age & Male & 86.4 & 13.6 & $* *$ \\
& <30 years & 70.2 & 29.8 & \\
& 30-50 years & 85.8 & 14.2 & \\
Education & 50-70 years & 87.0 & 13.0 & $* * *$ \\
& >70 years & 89.4 & 10.6 & \\
& < HS diploma & 79.9 & 20.1 & $* * * *$ \\
Community & HS diploma & 80.2 & 19.8 & \\
size & Some college & 85.2 & 14.8 & \\
& College degree & 87.1 & 12.9 & \\
\hline
\end{tabular}

$* *, * * *, * * * *$ significant at $\mathrm{P}=0.05,0.01$ and 0.001 respectively

impacted respondent views on drinking water safety (Table 2). Older respondents were more likely than people less than 30 years old to consider their drinking water safe. This difference is probably the result of younger residents being exposed to environmental education programs in schools over the last 20 years.

Education level also had an impact on drinking water satisfaction (Table 2). In 2017 Pacific Northwest residents that have attended college (some college + college degree) were more likely to consider their drinking water safe than residents with a high school diploma or less. Over the last 15 years (2002, 2007, 2012 and 2017), respondents with college degrees had the highest degree of satisfaction with their drinking water. Residents living in communities larger than 100,000 were less satisfied with the safety of their drinking water than people from smaller communities. This trend was not observed in 2007 and 2012.

\subsection{Surface water quality}

A majority of respondents considered surface water quality to be excellent or good in 2017 (Table 3). The general 15-year trend from 2002 to 2017 indicates a rising satisfaction with surface water quality since 2002 as a net percentage increase of $6.3 \%$ occurred in the excellent 
Table 3: Public views about the quality of surface waters (rivers, lakes) in the Pacific Northwest based on 2002, 2007, 2012 and 2017 surveys.

\begin{tabular}{lllll}
\hline Water quality & $2002(\%)$ & $2007(\%)$ & $2012(\%)$ & $2017(\%)$ \\
\hline Excellent or good & 45.3 & 41.3 & 57.7 & 51.6 \\
Fair & 37.3 & 41.7 & 37.8 & 39.0 \\
Poor & 8.6 & 10.4 & 6.0 & 7.1 \\
No opinion & 8.9 & 6.6 & 8.5 & 1.7 \\
\hline
\end{tabular}

or good category rating. Approximately $40 \%$ of the public has considered surface water quality fair since 2002 , while less than $11 \%$ considered surface water quality poor over the last 15 years. Less than $10 \%$ of surveyed residents used the no opinion/I don't know response over this 15 -year period. Basically, the survey results indicate that the public has had definite quality views of surface waters and that the percentages responses in the fair, poor and no opinion/I don't know categories have remained statistically similar since 2002.

The demographic factors of gender and age impacted how survey respondents viewed surface water quality over time (Tables 4 and 5). Conversely, the factors of education level and community size had no impact of views of surface water quality over time. When Pacific Northwest public views of surface water quality from the 2002 and 2017 surveys were compared, differences due to gender were significant (Table 4). First, males were more likely than females to rate surface water quality as excellent or good. Second, the differences between gender was significantly more pronounced in 2017 than in 2002 for the excellent or good category.

The demographic factor of age impacted surface water quality views over time (Table 5). Here, older survey respondents were more likely than people less than 40 to rate surface quality excellent or good in 2002. Conversely, this age impact was reversed with the 2017 survey results as older respondents were less likely to rate surface water quality excellent or good than respondents less than 40. Age did not impact fair and poor ratings in 2002 and 2017.

\subsection{Groundwater quality}

Based on surveys conducted in the region between 2002 and 2017, at least 37\% of the residents believed that the quality of groundwater in the Pacific Northwest was excellent or good. Public perceptions of groundwater quality have changed over the 15-year survey study

Table 4: The influence of the demographic factors of gender on public views of surface water quality based on the 2002 and 2017 Pacific Northwest water resources surveys.

\begin{tabular}{llllll}
\hline Year & Gender & Excellent/good $(\%)$ & Fair $(\%)$ & Poor $(\%)$ & No opinion $(\%)$ \\
\hline 2002 & Female & 43.7 & 38.6 & 9.9 & 7.8 \\
& Male & 46.9 & 36.0 & 7.8 & 9.3 \\
2017 & Female & 44.6 & 42.3 & 12.4 & 0.7 \\
& Male & 57.6 & 34.6 & 3.8 & 4.0 \\
\hline
\end{tabular}

2002 vs. 2017 data:****; 2002 gender vs. 2017 gender data: ****; **** =significant at $\mathrm{P}=0.001$; 
Table 5: The influence of the demographic factors of age on public views of surface water quality based on the 2002 and 2017 Pacific Northwest water resources surveys.

\begin{tabular}{llllr}
\hline Year & Age & Excellent/good $(\%)$ & Fair $(\%)$ & Poor $(\%)$ \\
\hline 2002 & $<30$ years & 42.0 & 38.8 & 9.6 \\
& $30-39$ & 40.6 & 38.6 & 10.3 \\
& $40-49$ & 46.5 & 34.0 & 8.3 \\
& $50-59$ & 44.0 & 34.1 & 12.1 \\
& $60-69$ & 46.2 & 37.2 & 7.1 \\
& $70+$ & 52.3 & 32.1 & 4.2 \\
& $<30$ years & 56.4 & 28.4 & 10.2 \\
& $30-39$ & 55.2 & 32.4 & 8.6 \\
& $40-49$ & 51.4 & 36.2 & 9.2 \\
& $50-59$ & 50.2 & 31.2 & 13.4 \\
& $60-69$ & 46.1 & 30.1 & 7.4 \\
& $70+$ & 47.3 & 29.4 & 12.3 \\
\hline
\end{tabular}

2002 vs. 2017 data: $* * * * ; 2002$ gender vs. 2017 age data: $* * * * ; * * *=$ significant at $\mathrm{P}=0.001$;

Table 6: Public views about the quality of groundwater in the Pacific Northwest based on 2002, 2007, 2012 and 2017 surveys.

\begin{tabular}{lcccc}
\hline Water quality & $2002(\%)$ & $2007(\%)$ & $2012(\%)$ & $2017(\%)$ \\
\hline Excellent or good & 37.1 & 38.5 & 50.0 & 46.2 \\
Fair & 34.1 & 33.1 & 25.9 & 21.6 \\
Poor & 3.9 & 5.4 & 2.7 & 16.7 \\
No opinion & 23.0 & 23.0 & 21.4 & 15.5 \\
\hline
\end{tabular}

(Table 6). Five major conclusions can be made from the survey responses. First, the public perception that groundwater quality is excellent or good increased in 2012 and 2017 compared to the 2002 and 2007 survey results. Second, compared to 2002, fewer people deemed groundwater quality fair in 2007, 2012 and 2017. Third, fewer than $10 \%$ of the public viewed groundwater quality poor in 2002, 2007 and 2012. Fourth, the perception of the public deeming groundwater quality poor significantly increased in 2017 compared to the other survey years. Fifth, over $15 \%$ of the public either had no opinion or did not know about groundwater quality in all years surveyed. This is in contrast to surface waters where well over $90 \%$ of the public had an opinion about water quality.

The demographic factors of gender and age impacted how Pacific Northwest residents viewed the quality of their groundwater (Tables 7 and 8). Conversely, the demographic factors of education level and community size did not have an impact about groundwater quality views. Males were more likely than females to rate groundwater quality excellent or good (Table 7). Both males and females were more likely to rate groundwater quality excellent or good in 2017 than in 2002. Part of this change may be due to less respondents selecting the no opinion choice in 2017. This change may be due to improved public awareness because of increased adult consumer education about water and watersheds. 
Table 7: The influence of the demographic factors of gender on public views of groundwater quality based on the 2002 and 2017 Pacific Northwest water resources surveys.

\begin{tabular}{llllll}
\hline Year & Gender & Excellent/good $(\%)$ & Fair $(\%)$ & Poor $(\%)$ & No opinion $(\%)$ \\
\hline 2002 & Female & 33.7 & 38.1 & 3.6 & 22.6 \\
& Male & 40.5 & 30.1 & 4.2 & 23.2 \\
2017 & Female & 39.3 & 23.4 & 19.3 & 18.0 \\
& Male & 53.1 & 19.8 & 14.1 & 13.0 \\
\hline
\end{tabular}

2002 vs. 2017 data:****; 2002 gender vs. 2017 gender data: ****; ****= significant at $\mathrm{P}=0.001$;

Table 8: The influence of the demographic factor of age on public views of groundwater quality based on the 2002 and 2017 Pacific Northwest water resources surveys.

\begin{tabular}{llllr}
\hline Year & Age & Excellent/good $(\%)$ & Fair $(\%)$ & Poor $(\%)$ \\
\hline 2002 & $<30$ years & 34.0 & 36.2 & 4.0 \\
& $30-39$ & 37.6 & 33.1 & 4.1 \\
& $40-49$ & 36.0 & 32.3 & 3.2 \\
& $50-59$ & 37.9 & 36.2 & 3.6 \\
& $60-69$ & 41.3 & 36.2 & 4.2 \\
2017 & $70+$ & 42.2 & 35.0 & 3.8 \\
& $<30$ years & 45.2 & 18.3 & 19.2 \\
& $30-39$ & 40.6 & 25.3 & 9.4 \\
& $40-49$ & 46.2 & 19.2 & 21.1 \\
& $50-59$ & 43.1 & 22.6 & 12.0 \\
& $60-69$ & 48.3 & 28.4 & 17.1 \\
& $70+$ & 50.2 & 19.4 & 14.2 \\
\hline
\end{tabular}

2002 vs. 2017 data:***; 2002 age vs. 2017 age data:**; ** and $* * *=$ significant at $\mathrm{P}=0.05$, and 0.01 , respectively;

Age significantly impacted the excellent or good groundwater quality selection in both 2002 and 2017 (Table 8). In general, older respondents had a more favourable view of groundwater quality than younger adults. The age by survey interaction showed that all age groups had a better opinion of groundwater quality in 2017 than in 2002.

\subsection{Perceived water quality pollutant issues}

In 2002, 2007, 2012 and 2017, Pacific Northwest residents were asked their concern of 10 potential contaminants in local waters. Results from the 2017 survey indicated that a large percentage of respondents chose 'don't know' when asked about the problems posed by specific contaminants (Table 9). Phosphates, nitrates, pesticides and minerals (associated with hard water) were chosen by more than $36 \%$ of respondents as causing problems in local water resources. Conversely, less than $20 \%$ of survey respondents identified petroleum products, pathogens, algae and salinity as local water resource problems.

When the 2002 and 2017 survey results were compared, significant trends about public perceptions of local water contaminants were observed (Table 10). Phosphates, nitrates and 
Table 9: Perceived water quality issues in waters of the Pacific Northwest based on 2017 survey.

\begin{tabular}{llll}
\hline Contaminant & Is a problem $(\%)$ & Not a problem $(\%)$ & Don't know $(\%)$ \\
\hline Phosphates & 43.8 & 10.0 & 40.2 \\
Nitrates & 40.7 & 17.2 & 42.1 \\
Pesticides & 38.9 & 22.2 & 38.9 \\
Minerals & 36.2 & 19.3 & 44.5 \\
Heavy metals & 28.3 & 34.5 & 37.2 \\
Pharmaceuticals & 25.3 & 22.4 & 52.3 \\
Petroleum products & 19.4 & 18.3 & 62.3 \\
Pathogens & 14.8 & 32.6 & 52.6 \\
Algae & 13.1 & 37.7 & 47.2 \\
Salinity & 12.5 & 44.1 & 43.4 \\
\hline
\end{tabular}

Table 10: Perceived water quality issues in waters of the Pacific Northwest based on 15-year trends by comparing results of the 2002 and 2017 surveys.

\begin{tabular}{lllll}
\hline Contaminant & Problem worse & Problem less & No change & Significance \\
\hline Phosphates & $\mathrm{X}$ & & & $* *$ \\
Nitrates & $\mathrm{X}$ & $\mathrm{X}$ & & $* * *$ \\
Pesticides & & $\mathrm{X}$ & $* *$ \\
Minerals & & $\mathrm{X}$ & $\mathrm{NS}$ \\
Heavy metals & & & $\mathrm{NS}$ \\
Pharmaceuticals & $\mathrm{X}$ & $\mathrm{X}$ & & $* * *$ \\
Petroleum products & & & $\mathrm{X}$ & $\mathrm{NS}$ \\
Pathogens & & $\mathrm{X}$ & $\mathrm{NS}$ \\
Algae & & $\mathrm{X}$ & $\mathrm{NS}$ \\
Salinity & & $\mathrm{NS}$ & \\
\hline
\end{tabular}

$* *, * * *, * * * *=$ significant at $\mathrm{P}=0.05,0.01$, and 0.001 respectively; $\mathrm{NS}=$ not significant.

pharmaceuticals were rated as a negative issues by significantly more people in 2017 compared to 2002. Conversely, pesticides and petroleum products were listed as issues by significantly less people in 2017 than in 2002. The recognition as an issue of heavy metals, pathogens, algae and salinity did not change over the 15-year survey study. The three contaminants, phosphates, nitrates and pharmaceuticals, which were more readily identified as problems in 2017 are explainable. First, pharmaceuticals were not readily identified as water problems in 2002. Since the initial survey, both science and the media have brought this category of contaminants to the attention of the public. Second, several research studies and media publicity about pharmaceuticals have made the public much more familiar to the average adult in the region.

\section{CONCLUSIONS AND RECOMMENDATIONS}

This repeated measures survey about water resources was important because it tracked public opinions over a 15 -year time period using four surveys with identical questions. The first survey (2002) provided baseline data while the following three surveys conducted at 5-year intervals were used to identify changes in public perceptions over time. This study was unique 
because virtually all published survey data on public perceptions of water resource issues have been based on a single point in time. The findings about drinking water quality support findings of other studies conducted in Canada, Great Brittan, France and Japan [11, 12]. Key findings of this study include:

- A large majority of Pacific Northwest residents were satisfied with the safety of drinking water at their home tap. In 2002, satisfaction with drinking water reached 91.3\%. However, the satisfaction with safety slipped in 2007, 2012 and was further reduced to $83.1 \%$ in the 2017 survey. These values are excellent, but the slippage in satisfaction should be addressed in the future.

- In 2017, a majority of survey respondents considered surface waters in the local areas to be excellent or good. The 15-year trend starting in 2002 indicated a rising satisfaction with surface water quality.

- The public image of groundwater quality has generally improved over the 15-year study. However, a significant portion of the public did not have an opinion about groundwater quality. Because of this finding, public education programs should be improved.

- An increasing percentage of the public over time indicated that they know or suspect that phosphates, nitrates and pharmaceuticals are a problem in local waters. Conversely, compared to 2002 study results, fewer people consider pesticides and petroleum products a problem.

- From a demographic factor standpoint, male respondents were more likely than females to say that drinking water was safe, and that both surface water and groundwater quality were excellent or good. Females were more likely than males to identify specific contaminants in local water as problematic.

This 15 -year survey study was data rich, as over 240,000 data points were collected. Since this 15-year study was unique and provided data that were useful for both educators and policy makers, it would be valuable to continue to conduct this survey at 5-year intervals in the future. The water resource in the region will likely become more limited due to both population growth and climate change in the future so it will become even more important to understand public attitudes and aptitudes toward water resources in the region.

\section{REFERENCES}

[1] Mahler, R.L., Simmons, R., Sorensen, F. \& Miner, J.R., Priority water issues in the Pacific Northwest. Journal of Extension, 42(5). Article 5RIB3, 2004, available at http:// www.joe.org/joe/2004october/rb3.php. Accessed May 1, 2013.

[2] Mahler, R.L., Simmons, R. \& Sorensen, F., Drinking water issues in the Pacific Northwest. Journal of Extension, 43(6), 6RIB6, 2005, available at http://www.joe.org/ joe/2005december/rb6.php. Accessed May 1, 2013.

[3] Gleick, P.H., The human right to water. Water Policy, 15, pp. 487-503, 1998. DOI: 10.1016/S1366-7017(99)00008-2

[4] Chenoweth, J.L., Minimum water required for social and economic development. Desalination, 229, pp. 245-256, 2008. DOI: 10.1016/j.desal.2007.09.011.

[5] Howard, G. \& Bartram, J., Domestic Water Quality, Service, Level and Health, World Health Organization: Geneva, 2003.

[6] Mahler, R.L., Barber, M.E. \& Shafii, B., Urban public satisfaction with drinking water since 2002 in the Pacific Northwest, USA. International Journal of Sustainable Development and Planning, 10(5) pp. 620-634, 2015. DOI: 10.2495/SDP-V10-N5-620-634. 
[7] Smith, R.A., Alexander, R.B. \& Wolman, M.G., Water quality trends in the nation's rivers. Science, 235, pp. 1607-1613, 1987. DOI: 10.1126/science.235.4796.1607.

[8] Mahler, R.L. \& Barber, M.E., Historical use of nitrogen and phosphorus in rain-fed regions and their consequential implications on water quality in the Pacific Northwest, USA. International Journal of Environmental Impacts, 1(3), pp. 334-343, 2018. DOI 10.2495/EI-V1-N3-334-343

[9] Sharpley, A.N., Chapra, S.C., Wedepohl, R., Sims, J.T., Daniel, T.C. \& Reddy, K.R., Managing agricultural phosphorus for protection of surface water: Issues and options. Journal of Environmental Quality, 23(3), pp. 437-451, 1993, DOI: 10.2134/jeq1994. oo472425002300030006x.

[10] Boyd, G.R., Reemtsma, H., Grimm, D.S. \& Mitra, S., Pharmaceuticals and personal care products (PPCPs) in surface and treated waters of Louisiana, USA and Ontario, Canada. Science of the Total Environment, 311(1-3) pp. 135-149, 2003. DOI: 10.1016/ S0048-9697(03)00138-4.

[11] Doria, M., Factors influencing public perception of drinking water quality. Water Policy, 12(1), pp. 1-19, 2010. DOI 10.2166/wp.2009.051

[12] Auslander, B.A. \& Langlos, P.H., Toronto tap water: Perception of its quality and use of alternatives. Canadian Journal of Public Health, 84(2), pp. 99-102, 1993.

[13] Wright, J.A., Yang, H., Rivett, U. \& Gundry, S.W., Public perception of drinking water safety in South Africa 2002-2009: A repeated cross-sectional study. BMC Public Health, 12, p. 556, 2012. DOI: 10.1186/1471-2458-12-556.

[14] Salent, P. \& Dillman, D., How to Conduct Your own Survey, John Wiley and Sons, Inc.: New York, NY, 1994.

[15] Dillman, D., Mail and Internet Surveys: The Tailored Design Method, John Wiley and Sons, Inc.: New York, NY, 2000.

[16] SAS Institute Inc., SAS Online Document 9.1.3, SAS Institute Inc.: Cary, NC, 2004. 